(C) 2021 Chioma Christiana Akuneme and Kingsley Chinaza Nwosu. This is an open access article licensed under the Creative Commons Attribution-NonCommercial 4.o International License (https://creativecommons.org/licenses/by-nc/4.o/)

\title{
French and Chinese Third Language Learners' Communication Apprehension in a Nigerian University: Influence of Prior Knowledge and Their Demographic Profiles
}

\author{
Chioma Christiana Akuneme \\ Department of Educational Foundations, \\ Nnamdi Azikiwe University, Awka, Nigeria \\ Kingsley Chinaza Nwosu \\ Postdoctoral Research Fellow, \\ Division of Student Affairs, University of the Free State, \\ South Africa
}

DOI: https://doi.org/10.36941/jesr-2021-0105

\begin{abstract}
Our study examined the influence of third language learners' prior knowledge and socio-demographic variables on their communication apprehension. Two hundred and twenty-six third language learners (French $n=136$ and Chinese $n=90$ ) participated in the study. Data obtained were subjected to point-biserial, multiple regression and t-test statistics. We found that participants' prior knowledge of their target languages has significant main effects on their communication apprehension. Significant mean differences occurred in the level of communication apprehension as a result of participants' gender, language of specialization and level of parental education. Regression analysis showed that the joint contribution of prior knowledge, parental level of education, language of specialization and gender on third language learners' communication apprehension was significant; contributing $13.4 \%$ to explain the variances in response. Language of specialization and prior knowledge made significant individual contributions to students' communication apprehension with language of specialization being the most individual contributor to the variances in students' responses. Our study has implications for curriculum planners given that if third language curricula are designed to link what is learnt in the university to what is learnt at the primary and secondary schools, learners will find the target language familiar, which may help them overcome the feelings of communication apprehension.
\end{abstract}

Keywords: Chinese language, French Language, communication apprehension, third language, prior knowledge and demographic variable

\section{Introduction}

Employability of foreign language students after they have graduated from school is largely dependent on their communication competence (Meghar \& Chuah, 2012). This explains why proficiency in a foreign language is pivotal to third language learners. However, research has shown 
that despite the efforts some foreign language students make in order to develop their speaking skills, communication apprehension has continued to pose as a major psychological challenge hindering them from attaining the desired level of proficiency in their oral performance (Nuraqilah \& Aminabibi, 2019). Communication apprehension is simply referred to as the anxiety to communicate with people (Kralova, 2016). Over the years, studies have demonstrated that the majority of foreign language learners do suffer from this problem, and that the level of the apprehension ranges from moderate to high (Balemir, 2009; Nuraqilah \& Aminabibi, 2019; Rafel et. al., 2014).

Foreign language students, chronologically, have the foreign language being studied as either the first or second foreign language they have encountered throughout their lifetime. According to Hammaberg (2018), students who have the foreign language being studied as their first foreign language are regarded as second language learners while students who are in the process of learning a second or additional foreign language are referred to as third language learners. In Nigeria, English language is usually learnt as the first foreign language. This is because English language is the nation's lingua franca and functions generally as a language of communication among people of different ethnic groups in the country. Meanwhile, additional foreign languages such as French and Chinese are also learnt in Nigeria. Anchoring on Hammerberg's (2018) assertion, learners of English language in Nigeria can be referred to as second language learners while learners of French and Chinese can as well be referred to as third language learners.

Considering the issue of communication apprehension, third language learners, particularly in Nigeria may have a greater tendency of being communication apprehensive. This is based on the fact that foreign languages learnt as third languages in Nigeria may not be sufficiently practiced in real life contexts of the target language. The reason being that third languages are known to be spoken only by a knowledgeable few, and in limited contexts too which are mainly the classrooms (Lana \& Yahya, 2013). By implication, third language learners in Nigeria are limited to practicing their target languages solely in the classroom contexts. This could pre-dispose them to communication apprehension. As might be expected, being limited to practicing a foreign language solely in the classroom contexts is unlikely to guarantee sufficient practice in that language, and lack or insufficient practice in a foreign language is one of the major causes of communication apprehension (Sadighi \& Dastpak, 2017).

Communication apprehension is also believed to be associated with specific negative effects such as avoidance of communication in the target language by students especially in front of an audience, development of low self-esteem, withdrawal, reticence etc. (Molnar \& Crnjak, 2018; Mustapha \& Khalil, 2018). The extent to which communication apprehension and its associated adverse effects manifest is dependent on a number of factors which may include students' prior knowledge of the target language before studying it at the university level, parental level of education, language of specialization and gender.

Prior knowledge refers to the totality of information that learners have about a subject matter (Brandao \& Oakhill, 2005). The need to investigate prior knowledge as a potential contributory factor to foreign language students' communication apprehension is informed by Zashchitina and Moysyak's (2017, p.2) assertion that "foreign language students learn effectively when they already know something about a content area and when concepts in that area are familiar to them". This could suggest that students who already had a prior knowledge of a foreign language before studying it at the university level may tend to experience lower level of communication apprehension. In Nigeria, while French language learning is officially incorporated in both the primary and secondary school curriculum, Chinese language is not. Chinese language students are thereby presumed to have just encountered the language at the university level and thereby had no prior knowledge of the target language before studying it at the university level. In view of this, one could postulate that Chinese language students may be more communication apprehensive than French language students.

Considering the influence of parental level of education on the communication apprehension of students, Muruwei (2011) opined that the level of education of parents is perceived seen as a significant factor in their language learning. Parental level of education reveals whether the parents of foreign language students are educated or not. According to Murith (2015), while some parents 
encourage and support their children to learn additional foreign languages, some do not. The difference in the level of support and attitude of these different groups of parents may be based on the differences in their level of educational attainment (Bago, 2018). Parents who are more educated are more likely to understand the benefits of learning a foreign, and may also be more inclined to knowing the steps to take in guiding their children towards being successful in foreign language learning (Hosseinpour, Sherkatolabbasi \& Yarahmadi, 2015). On the other hand, though parents with lower or no level of education may be concerned about their children's academic challenges, it is perceived that they lack the intellectual capacity to construct ideas and guide their children properly towards academic success (Singh, Horo \& Singh, 2016). By implication, children of educated parents are likely to develop a more positive and confident attitude when faced with an academic challenge than the children whose parents lack education (Khan, Iqbal \& Tasneem, 2015).

Language of specialization is another variable of interest that could explain communication apprehension experienced among third language learners. Language of specialization has to do with the specific language of interest studied by students. In the context of our study, some participants have their specialty in the study of French language, while some specialized in Chinese language. The essential roles these languages; French (Omonigho, 2016) and Chinese (Odinye, 2015) play in Nigeria point to the need to study them as full-fledged academic courses in Nigerian universities. Though French language is the second official language in Nigeria, it is still poorly learnt especially at both the primary and secondary schools levels. On the other hand, Chinese language is perceived to be difficult to learn, considering its 'character-based writing system and tonal nature' (Luo, 2014). It is possible that these peculiarities evident in French and Chinese languages could make their learners experience anxiety when speaking in the language. Hence, there is a need to investigate if language of specialization could be a contributory factor to third language learners' communication apprehension.

Another demographic variable that would be considered in this study is the gender of learners. The influence of gender on foreign language students' ability to successfully attain proficiency in the four language skills has been investigated particularly, with respect to foreign language anxiety as a whole (Aydin et. al, 2017). Adequate attention has not been given specifically to the study of gender influence on communication apprehension (Stawiarska \& Malgorzata, 2014). Meanwhile, Churgai (2015) explained that there is a perceived tendency that men and women differ in their ability to communicate in a language. Based on this assertion, it becomes necessary to also investigate if the differences in the level of communication apprehension experienced among third language learners is actually related to their gender differences.

\section{Literature Review}

In the field of foreign language learning, communication apprehension is a major challenge faced by most foreign language students. Speaking in a foreign language which is one of the main goals of learning a language, and which ordinarily should be a much desired or fun activity has, on the contrary, shown to lead communication apprehension (Ozturk \& Gurbuz, 2013; Shabani, 2013). Amara (2018) reported that some foreign language students experience communication apprehension due to inadequate practice time, insecurity and fear. To reduce the adverse effects of communication apprehension on foreign language students' speaking skills, researchers and educators are working indefatigably to investigate the variables that contribute to foreign language students' communication apprehension.

The study by Shabani (2013) involved 10 English foreign language students in Iran conducted in a pre-university class. The results revealed that prior knowledge has a significant effect on students' ability to speak fluently in a foreign language. From his study, he noted that the more background knowledge students have about a topic or a subject matter, the more they can easily talk about them. Hasan, Gushendra and Yonantha (2017) found a strong positive correlation between prior knowledge and students' listening comprehension. They concluded that the influence of prior knowledge on students' listening comprehension is very high. Seery (2009) therefore submitted that prior 
knowledge provides students with an established background on which to build future knowledge and as a result, students with a prior knowledge tend to approach a subject with a more confident and positive attitude than students who do not have a prior knowledge.

Researchers have reported that having a prior knowledge of a subject matter before studying it at a more advanced level influences students' achievement, and as well contributes to their learning (Arifin, 2019; Hailikari \& Ylanne, 2008; Star et. al., 2009). In 2012, Yeh examined how prior knowledge can influence students' gaining of an understanding when reading Chinese as a second language and found prior knowledge was influential on deeper understanding of the language. A study by Liu, Lin \& Paas (2014) involving eighty-one fifth grade students was conducted in a primary school in Taiwan. The findings from both the first and second experiment of the study revealed significant difference in the performances of those with higher prior knowledge and those with lower prior knowledge. In line with these, Nioutsikos (2017) recommended that it is pertinent to assess students' prior knowledge at the beginning of an academic activity in order to discover what they already know and so as to also facilitate their learning experience.

Zhou (2020) in his study noted that parental education is a factor that has an impact on second language learning. He posits that while some parents are involved in their wards' learning of a second language, others play a passive role; and that the difference in parental attitude towards foreign language learning may be dependent on their education. Khan, Iqbal and Tasneem (2015) found that parents with higher educational attainment are usually interested in their children's learning and that to some extent, they have more influence on their children which invariably leads to the children's academic success. Terfassa (2018) examined the association that exists between the education level of parents and pupils' academic output in Dire Dawa, Ethiopia and found that a significant relationship.

Similar studies on educational level of parents and students' performance in foreign language learning indicated that the level of education of parents significantly influence students' learning (Bakar, Mamat \& Ibrahim, 2017; Chemagosi, 2020; Musarat et. al, 2013; Odoh, Ugwuanyi, Odigbo \& Chukwuani, 2017). In addition, Khodadady and Alaee (2012) conducted a study involving 1352 high school students in Mashdad which revealed a significant difference between the English foreign language (EFL) achievement of third graders whose parents have a higher level of education and those whose parents have a lower level of education. Muruwei (2011) concluded that the higher parental education is a determinant to their children excelling and performing better in their studies. Panferov (2010) recommended that there is a need for English Language learners' (ELL) parents to be literate enough to ascertain the educational and literary needs of their children as it tends to exert a positive influence in learning a foreign language.

Though it appears to be difficult to find studies that have compared communication apprehension of third language learners who specialize in different language courses, there is research evidence showing that some language languages may evoke communication apprehension more than others. The study by Luo (2014) involving 257 Chinese foreign language (CFL) learners at two large public universities in the U.S. revealed that College-level CFL learners in the U.S were not highly anxious about communicating in Chinese. Zhao and Whitchurch (2011) also found that the mean item response for English-speaking CFL learners' language anxiety was not very high, indicating that they were just a little anxious about learning Chinese. On the other hand, Darmawangsa and Sukmayadi (2020) examined first year students' communication apprehension in learning French as a foreign language and found that with an average overall score of 73.2 , the first year students 'communication apprehension ranged from moderate to high. They concluded from their findings that these students tend to experience communication apprehension when they are asked to speak publicly in a foreign language. In addition, a study conducted by Obinna, Maduagwu, Nelson and Onyeka (2019) involving 300 senior secondary school French students in Imo state, Nigeria, showed that communication apprehension is high among the French students.

Furthermore, research on gender as one of the factors influencing the level of apprehension experienced among foreign language students when speaking in a foreign language have yielded conflicting results. According to Cagatay (2015), most studies reveal with empirical evidence that 
females are more communication apprehensive than males. Vasiliki et. al., (2015) also found that females experience higher level of anxiety when communicating in English as a second language than their male counterparts. In contrast, Dogan \& Tuncer (2016) documented that males experience a higher level of communication apprehension than females. Meanwhile, Ying (2018) demonstrated that there are no gender differences relating to communication apprehension.

From the review, it can be observed that most available studies carried out were mainly on learners of English language as a foreign language (EFL) and a second language (L2). Most of the studies were on second language learners, with little or no attention given to third language learners. Furthermore, literature appears to be inadequate to help researchers understand communication apprehension among learners of other foreign languages other than English language. Specifically, the influence of prior knowledge and demographic factors on communication apprehension of third language learners appears grossly underexplored. This study, therefore, seeks to address these gaps in literature. To understand the issue of communication apprehension of third language learners, the role of prior knowledge and three demographic factors which are parental level of education, language of specialization and gender were explored. The following research questions are formulated to guide the study.

1. What are participants' mean scores on communication apprehension?

2. What is the relationship between the participants' prior knowledge, demographic variables (parental level of education, language of specialization, gender) and their communication apprehension?

It was also hypothesized that:

1. Significant differences do not occur in third language learners' responses based on their prior knowledge and demographic variables (parental level of education, language of specialization, gender).

2. There is no significant relationship between third language learners' prior knowledge, demographic variables (parental level of education, language of specialization, gender) and communication apprehension.

3. Third language learners' prior knowledge, parental level of education, language of specialization and gender do not significantly predict their communication apprehension.

\section{Methodology}

The study adopted a descriptive survey research design. Loeb et al (2017) posited that a descriptive survey research is appropriate for a study that describes a population or a phenomenon. It can answer questions about what, where, when, who and to what extent. The population of the study consisted of all the undergraduate French and Chinese language students in Nnamdi Azikiwe University, Awka during the 2020-2021 academic year. The total number of these students is 321 (which comprised 185 French students and 136 Chinese students). This number excludes the fifty three 30o-level French and Chinese students (French $n=38$ and Chinese $n=15$ ) who were doing their one year immersion program abroad. As the study was conducted during the second phase of the Covid-19 pandemic, the researchers made use of the Google forms in Google docs to get through to the respondents. The items of the instruments were embedded in the Google docs. The Google docs with the link https://docs.google.com/forms/d/e/1FAIpQLSctWVZHWkC_Vgogn7IscLlP-WIJ_kimboFn_qUwTg; P YIoC6w/viewform - was sent to the French students' WhatsApp platform with the aid of their course representatives. Another Google docs link - https://docs.google.com/forms/d/e/1FAIpQLSdEfvm GeF8rYo7UHW5iXrAWzq9Efj8fIG8kM2ylgfgnj92ALw/viewform - was sent to the Chinese students WhatsApp platform also with the aid of their course representatives. These course representatives facilitated the students to respond to the instruments. On the whole, a total of 226 students (French $\mathrm{n}=136$ and Chinese $\mathrm{n}=90$ ) responded, representing $70.4 \%$ of the total population (French $\mathrm{n}=73.51 \%$ and Chinese $n=66.17 \%$ ). In other words, 226 students (French $n=136$ and Chinese $n=90$ ) who gave their consent to the study were used. Their responses were received within a period of one month - 
19th January, 2021 through 19th February, 2021.

\section{Research Instruments}

Data were gathered with these adapted survey instruments: the Prior Knowledge Inventory (PKI) and the Foreign Language Communication Apprehension Questionnaire (FLCAQ). The researchers used the demographic section of the questionnaire to get the background information of the participants in three subcategories: parental level of education, language of specialization and gender. Parents who never obtained a post-secondary education qualification were considered to have low educational qualifications while those who acquired a tertiary education qualification were considered to have high educational qualification. The PKI consisted of 5 items that explored whether the language students had acquired any knowledge of their target language before enrolling to study it at the university level. They were modified from Nioutsikos' (2017) Prior Educational Experience (PEE). The FLCAQ addressed students' communication apprehension, which consisted of 10 questions that were selected and adapted from Horwitz, Horwitz and Cope's (1986) Foreign Language Classroom Anxiety Scale (FLCAS). The reliability coefficients of the instruments were established using Cronbach's alpha. The reliability coefficients were 0.71 for PKI and 0.89 for FLCAQ. Pointbiseral, multiple regressions and the independent t-test statistics were used for data analysis.

\section{Result}

Table 1: Respondents' Characteristics

\begin{tabular}{|c|c|c|c|}
\hline Variable & & Frequency & Percentage \\
\hline \multirow[t]{9}{*}{ Highest Level of Fathers' education } & No education & 9 & 4.0 \\
\hline & FSLC & 58 & $25 \cdot 7$ \\
\hline & WASSCE/NECO/GCE & 59 & 26.1 \\
\hline & OND & 8 & $3 \cdot 5$ \\
\hline & NCE & 9 & 4.0 \\
\hline & $\mathrm{HND} / \mathrm{BSC} / \mathrm{BA}$ & 43 & 19.0 \\
\hline & Masters & 21 & $9 \cdot 3$ \\
\hline & PHD & 19 & 8.4 \\
\hline & Total & 226 & 100.0 \\
\hline \multirow[t]{9}{*}{ Highest Level of mother's education } & No education & 8 & $3 \cdot 5$ \\
\hline & FSLC & 38 & 16.8 \\
\hline & WASSCE/NECO/GCE & 71 & 31.4 \\
\hline & OND & 5 & 2.2 \\
\hline & NCE & 13 & 5.8 \\
\hline & $\mathrm{HND} / \mathrm{BSC} / \mathrm{BA}$ & 53 & 23.5 \\
\hline & Masters & 26 & 11.5 \\
\hline & PHD & 12 & $5 \cdot 3$ \\
\hline & Total & 226 & 100.0 \\
\hline \multirow[t]{3}{*}{ Categorization of fathers' levels of Education } & low education & 127 & 56.2 \\
\hline & high education & 99 & 43.8 \\
\hline & Total & 226 & 100.0 \\
\hline \multirow[t]{3}{*}{ Categorization of mothers' levels of Education } & low education & 114 & 50.4 \\
\hline & high education & 112 & 49.6 \\
\hline & Total & 226 & 100.0 \\
\hline \multirow[t]{3}{*}{ Gender } & Male & 61 & 27.0 \\
\hline & Female & 165 & 73.0 \\
\hline & Total & 226 & 100.0 \\
\hline \multirow[t]{3}{*}{ Language of Specialization } & French & 135 & $59 \cdot 7$ \\
\hline & Chinese & 91 & 40.3 \\
\hline & Total & 226 & 100.0 \\
\hline
\end{tabular}


Table 1 showed the respondents' characteristics. The majority of the parents of the respondents did not attend tertiary institutions with the mothers possessing a greater number of higher education qualifications than the fathers of the respondents. Thus, the parents' highest level of education falls within low education category. Also, female students constituted the majority of the respondents; while the majority of the respondents specialized on French language.

Table 2: Mean Scores, Standard Deviation and ANOVA Test on Prior Knowledge and Communication Apprehension

\begin{tabular}{|c|c|c|c|c|c|c|c|}
\hline Variables & & No & Mean on Comp. Appr. & Stand Dev & $\mathrm{df}$ & F-value & Sign \\
\hline \multirow{5}{*}{$\begin{array}{l}\text { I learnt French/Chinese in } \\
\text { primary school only }\end{array}$} & Not at all & 147 & 2.71 & .48 & & \multirow{5}{*}{4.439} & \multirow{5}{*}{.005} \\
\hline & a bit & 53 & 2.99 & .52 & 3 & & \\
\hline & moderately well & 16 & 2.72 & .54 & & & \\
\hline & very well & 10 & 2.67 & .35 & & & \\
\hline & Total & 226 & 2.78 & .50 & 222 & & \\
\hline \multirow{5}{*}{$\begin{array}{l}\text { I learnt French/Chinese in } \\
\text { secondary school only }\end{array}$} & Not at all & 115 & 2.72 & .52 & & \multirow{5}{*}{2.677} & \multirow{5}{*}{.048} \\
\hline & a bit & 84 & 2.88 & .46 & 3 & & \\
\hline & moderately well & 21 & 2.80 & .55 & & & \\
\hline & very well & 6 & 2.42 & .30 & & & \\
\hline & Total & 226 & 2.78 & .50 & 222 & & \\
\hline \multirow{5}{*}{$\begin{array}{l}\text { I learnt French/Chinese in both my } \\
\text { primary and secondary school }\end{array}$} & Not at all & 113 & 2.72 & .48 & & \multirow{5}{*}{3.661} & \multirow{5}{*}{.013} \\
\hline & a bit & 75 & 2.91 & .50 & 3 & & \\
\hline & moderately well & 28 & 2.77 & .54 & & & \\
\hline & very well & 10 & 2.45 & .47 & & & \\
\hline & Total & 226 & 2.78 & .50 & 222 & & \\
\hline \multirow{5}{*}{$\begin{array}{l}\text { I learnt French/Chinese in a } \\
\text { French/Chinese country }\end{array}$} & Not at all & 174 & 2.80 & .51 & & \multirow{5}{*}{3.020} & \multirow{5}{*}{.031} \\
\hline & a bit & 35 & 2.81 & .46 & 3 & & \\
\hline & moderately well & 8 & 2.43 & .43 & & & \\
\hline & very well & 9 & 2.43 & .32 & 222 & & \\
\hline & Total & 226 & 2.78 & .50 & 222 & & \\
\hline \multirow{5}{*}{$\begin{array}{l}\text { There is a link between the module } \\
\text { of syllabus of French/Chinese in the } \\
\text { university and the prior knowledge I } \\
\text { already had before enrollment }\end{array}$} & Not at all & 96 & 2.83 & .56 & & \multirow{5}{*}{.772} & \multirow{5}{*}{.511} \\
\hline & a bit & 84 & 2.76 & .40 & 3 & & \\
\hline & moderately well & 26 & 2.67 & .54 & & & \\
\hline & very well & 20 & 2.75 & .53 & \multirow{2}{*}{222} & & \\
\hline & Total & 226 & 2.78 & .50 & & & \\
\hline
\end{tabular}

ANOVA statistics in Table 2 showed a significant main effect of students' responses on the level of their prior French/Chinese learning experience in primary school on their communication apprehension $F(3,222)=4.439, p<.05$.

There was also significant main effects of students' responses on the level of their prior French/Chinese learning experiences in secondary schools on their communication apprehension, $F(3,222)=2.677, p<.05$; in learning in both primary and secondary schools on their communication apprehension, $F(3,222)=3.661, p<.05$; in the country of where the French/Chinese is a lingua Franca on their communication apprehension $F(3,222)=3.020, p<.05$.

However, there was no significant main effect in the responses of students regarding the level of the link between the module of syllabus of French/Chinese in the university and their prior knowledge before enrollment in the university on their communication apprehension $F(3,222)=.772$, $p>.05$. 
Table 3: T-test Statistic on Mean Differences according to Respondents' Gender and Fathers' Education, Mothers' Education, Language of Specialization and their communication apprehension

\begin{tabular}{|c|c|c|c|c|c|c|}
\hline Variables & Demographic & Mean & Std. Deviation & $\mathrm{t}$ & $\mathrm{df}$ & sign \\
\hline Gender and communication & Male & 2.70 & .50 & \multirow{2}{*}{-1.426} & \multirow[b]{2}{*}{224} & \multirow[b]{2}{*}{.155} \\
\hline apprehension & Female & 2.81 & .50 & & & \\
\hline Father Education and & Low Education & 2.73 & .49 & \multirow{2}{*}{-1.502} & \multirow[b]{2}{*}{224} & \multirow{2}{*}{.134} \\
\hline communication apprehension & High Education & 2.83 & .52 & & & \\
\hline Mother Education and & Low Education & 2.76 & .50 & \multirow{2}{*}{-.478} & \multirow{2}{*}{224} & \multirow{2}{*}{.633} \\
\hline communication apprehension & High Education & 2.79 & .51 & & & \\
\hline Language of Specialization and & French & 2.89 & .50 & \multirow{2}{*}{4.103} & \multirow[b]{2}{*}{224} & \multirow{2}{*}{.000} \\
\hline communication apprehension & Chinese & 2.62 & .46 & & & \\
\hline
\end{tabular}

Table 3 shows that male students $(M=2.70, S D=.50)$ had a non-significant lower mean score in their communication apprehension than their female counterparts $(M=2.81, S D=.50), t(224)=-1.426, p$ $>.05$. Furthermore, respondents whose fathers had low education $(M=2.73, S D=.49)$ had a nonsignificant lower mean score in communication apprehension than their counterparts whose fathers had high education $(M=2.83, S D=.52), t(224)=-1.502, p<.05$; while respondents whose mothers had low education $(M=2.76, S D=.50)$ had a non-significant marginally lower mean score in communication apprehension than their counterparts whose mothers had high education $(M=2.76$, $S D=.51), t(224)=-.478, p<.05$. However, students whose language of specialization is French language had a significant higher mean score in communication apprehension than their counterparts whose language of specialization is Chinese $(M=2.89, S D=.50), t(224)=4.103, p<.05$.

Table 4: Correlation Matrix of Students' Prior Knowledge, Level of Mother and Father Education, Language of Specialization, Gender and Communication Apprehension

\begin{tabular}{|c|c|c|c|c|c|c|}
\hline Variable & 1 & 2 & 3 & 4 & 5 & 6 \\
\hline Prior knowledge & - & & & & & \\
\hline Level of mother education & .109 & - & & & & \\
\hline Level of father education & .017 & $.409^{* *}$ & - & & & \\
\hline Language of specialization & $-.568^{* *}$ & -.038 & -.034 & - & & \\
\hline Gender & $.217^{* * *}$ & .044 & -.066 & $-.273^{* *}$ & - & \\
\hline Communication apprehension & -.040 & .032 & .100 & $-.264^{* *}$ & .095 & - \\
\hline
\end{tabular}

Table 4 showed the relationship existing between the independent variables and the dependent variable. It showed that prior knowledge, level of mother and father education, and gender had no significant relationships with communication apprehension, $r(226)=-.040, p>.05 ; r(226)=.032$, $p>.05 ; r(226)=.095, p>.05$ respectively. However, the language of specialization had negative significant relationship with communication apprehension $r(226)=-.264, p<.05$.

Table 5: Multiple Regression Analysis for Predictor Variables and Communication Apprehension

\begin{tabular}{|c|c|c|c|c|c|}
\hline \multirow{2}{*}{ Model } & \multicolumn{2}{|c|}{ Unstandardized Coefficients } & \multirow{2}{*}{$\begin{array}{c}\text { Standardized Coefficients } \\
\text { Beta }\end{array}$} & \multirow{2}{*}{$\mathrm{t}$} & \multirow{2}{*}{ Sig. } \\
\hline & $\mathrm{B}$ & Std. Error & & & \\
\hline (Constant) & 3.262 & .230 & & 14.151 & .000 \\
\hline Gender & .057 & .074 & .051 & .772 & .441 \\
\hline Level of father edu & .092 & .070 & .091 & 1.314 & .190 \\
\hline${ }^{1}$ Level of mother edu & .008 & .069 & .008 & .118 & .906 \\
\hline Language of specialization & -.418 & .079 & -.410 & -5.268 & .000 \\
\hline Prior knowledge & -.232 & .062 & -.286 & -3.722 & .000 \\
\hline $\mathrm{R}$ & $.366^{\mathrm{a}}$ & & & & \\
\hline $\mathrm{R}^{2}$ & .134 & & & & \\
\hline $\mathrm{F}$ & 6.810 & & & & .000 \\
\hline
\end{tabular}


The result in Table 5 shows that the multiple regression coefficients (R) were .366 while $\mathrm{R}^{2}$ was .134 . This is an indication that the predictor variables jointly contributed $13.4 \%$ to explain the variances in response and the corresponding $\mathrm{F}(5,220)=6.810$, is statistically significant $(\mathrm{p}<.05)$. Using standardized (B), the table indicated that language of specialization and prior knowledge made significant individual contributions to students' communication apprehension with language of specialization being the most individual contributor to the variances in response.

\section{Discussion}

This study primarily sought to investigate the impact of third language learners' prior knowledge, demographic variables (parental level of education, language of specialization, gender) on their communication apprehension. Parental level of education is separated into Fathers' and Mothers' level of education, with these levels of education categorized into high or low. Under language of specialization, some of the participants are specialized in French language, others are third language learners of Chinese.

Preliminary findings of the study revealed that majority of the parents of the participants have low level of education, with the mothers possessing a greater number of higher education qualifications than the fathers. Also, female students constituted the majority of the participants; while the majority of the participants also specialized in the study of French language. This analysis is done in order to give an overview of the participants' characteristics. It is also believed that these participants' characteristics are relevant in understanding the findings of the study.

One important finding of this study is the impact of participants' prior knowledge on their communication apprehension. Participants' prior knowledge of their target languages which they acquired either at the primary school level, secondary school level, both primary and secondary school levels and also during their study abroad, all have significant main effects on their communication apprehension. The least mean scores on communication apprehension occurred when students responded that they had firm prior knowledge on the target language before studying the language in the university. This is in agreement with the findings of Shabani (2013) which showed that prior knowledge has a significant effect on students' ability to speak fluently in a foreign language. Shabani (2013) also noted that the more prior knowledge students have about a topic or a subject matter, the more they can easily talk about them. Similar studies also demonstrated that prior knowledge influence students' performance (Arifin, 2019; Star et. al., 2009). This could imply that having prior knowledge of a target language impacts third language learners' communication apprehension. Considering the link between the module/syllabus of French/Chinese in the university and the students' prior knowledge, our findings showed no significant main effect of this link on participants' communication apprehension. This could be due to the fact that the syllabus at the university level may be more advanced than the syllabus encountered by third language learners at lower levels of their education. Also, the module/syllabus during their immersion programme may also differ since most of the activities at this level may be influenced by the culture of the owners of the target language.

Taking gender into consideration, the findings from this study showed that male students had a non-significant lower mean score in their communication apprehension than their female counterparts. Though non-significant, the finding implies that female students may be more communication apprehensive than males. This corroborates with a similar study by Vasiliki et. al., (2015) which revealed that female students experience higher level of anxiety when communicating in English as a second language than their male counterparts. Cagatay (2015) also noted that most studies reveal that female students are more communication apprehensive than male students. This could be as a result of their shy and sensitive nature. However, there are also other works which have shown contradictory findings (Dogan \& Tuncer, 2016; Ying, 2018). This is an indication that research on the impact of gender differences on communication apprehension needs more in depth investigations. 
Another important finding of the study is the impact of parental level of education on participants' communication apprehension. Participants whose fathers had low education had a nonsignificant lower mean score in communication apprehension than their counterparts whose fathers had high education. In the same vein, participants whose mothers had low education had a nonsignificant marginally lower mean score in communication apprehension than their counterparts whose mothers had high education. Generally, this implies that though non-significant, students whose parents had high level of education tend to experience communication apprehension more than their counterparts. This finding contradicts that of Muruwei (2011) who found that the more educated parents are, the more likely it is that their children will excel and perform better in academic-related challenges. However, it could be that due to the interest these educated parents show in their children's ability to communicate in a foreign language, some learners may feel pressured to the point that they become apprehensive.

Considering the impact of language of specialization on the communication apprehension of third language learners, results from the study revealed that students whose language of specialization is French language had a significant higher mean score in communication apprehension than their counterparts whose language of specialization is Chinese. This implies that French language students are likely to suffer more from communication apprehension than Chinese students. This is in line with Obinna, Maduagwu, Nelson and Onyeka's (2019) findings that communication apprehension evoked the highest level of anxiety among French students. Luo (2014) also revealed that College-level CFL learners in the U.S were not highly anxious about communicating in Chinese. This could be due to the fact that since Chinese language is relatively new in Nigeria (Odinye, 2015), it has lot of incentives and rewards which motivate Chinese students to be able to speak the language and combat any feeling of communication apprehension. On the other hand, though French language has been in vogue as the nation's second official language (Omonigho, 2016), it may have had its enticing rewards at the beginning, but the incentives that motivate students to learn and speak the language, may have also drastically reduced with time. When foreign language students are less motivated, they are likely not going to have the zeal to practice or speak in their target languages and lack of practice in a target language according to Sadighi \& Dastpak (2017) is also one of the major causes of communication apprehension.

The multiple regression analysis conducted in the study also showed that the predictor variables accounted for $\mathbf{1 3 . 4 \%}$ variances in third language learners' communication apprehension. However, when looking at the relative contributions of the variables, the results showed that language of specialization and prior knowledge made significant individual contributions to students' communication apprehension with language of specialization being the most individual contributor to the variances in response. This finding is consistent with that of Luo's (2014) and Obinna, Maduagwu, Nelson and Onyeka's (2019) in which languages of specialization were seen to influence Chinese/French students' level of communication apprehension. The present finding also supports that of Shabani (2013), who concluded that the more prior knowledge students have about a topic or a subject matter, the more they can easily talk about them. More so, this implies that prior knowledge is seen to play a significant role in overcoming communication apprehension.

\section{Limitations/Implications}

The study has limitations which could affect the generalizability of the findings. First is the fact that the data used in the study were obtained from one single university in Nigeria. This could limit the findings of this study to only that university. Another limitation to the study arose as a result of using only a survey questionnaire. Given the fact that communication apprehension is a subjective feeling which is peculiar to each participant, employing a mixed method approach which would involve interviewing some selected students, would have given more robust findings to the study instead of using only questionnaires.

However, the findings of the study has significant educational implications for curriculum 
planners in Nigeria. In planning third language learners' curriculum, curriculum planners need to plan it in such a way that there would be a link between the module of syllabus of French/Chinese taught at the university level and also those taught at both the primary and secondary school levels. Based on the findings, it becomes pertinent that foreign languages should first be taught properly at the primary and secondary school levels in order to enable students to learn them effectively as fullfledged academic courses at the university level.

\section{Conclusion}

This study was necessitated due to the growing concern over the continued experience of communication apprehension among third language learners. Findings from the study have revealed the impact of prior knowledge on third language learners' communication apprehension. Regression analysis also showed that language of specialization and prior knowledge predicted third language learners' communication apprehension. It is concluded therefore that the communication apprehension experienced among third language learners may be linked to factors such as the peculiarity and uniqueness of the language being studied, that is their language of specialization, and also to the level of prior knowledge.

\section{References}

Amara, N. (2018). Oral communication apprehension among ESP students in Algeria. Arabic Language Literature ECulture, 3(3), 22-28. doi:10.11648/j.allc.20180303.11

Arifin, I. N. (2019). The effect of prior knowledge on students' learning outcomes on the subject of basic science concepts. Advances in Social Science, Education and Humanities Research, 382, 158-16o. http://creativecom mons.org/licenses/bync/4.o/

Aydin, S., Harputlu, L., Celik, S. S., Ustuk, O. \& Guzel, S. (2017). Age, gender and grade effect on foreign language anxiety among children. TEFLIN Journal, 28(2), 135 154. doi: http://dx.doi.org/10.15

639/teflinjournal,v28i2/135-154

Balemir, H. S. (2009). The sources of foreign language speaking anxiety and the relationship between proficiency level and degree of foreign language speaking anxiety. (Unpublished master's thesis, Bilkent University, Ankara.)

Bago, V. (2018). The attitudes of parents towards early foreign language learning. (Master's thesis, University of Rijeka.) https://urn.nsk.hr/urn:nbn:hr:186:390917

Bakar, N. A., Mamat, I. \& Ibrahim, M. (2017). Influence of parental education on academic performance of secondary school students in Kuala Terengganu. International Journal of Academic Research in Business and Social Sciences, 7(8), 296-304. http://dx.doi.org/10.6007/ijarbss/v7-i8/3230

Brandao, A. C. P., \& Oakhill, J. (2005). How do you know this answer? Children's use of text data and general knowledge in story comprehension. Reading and Writing 18, 687 713. doi:10.1007/s11145-005-560o-x

Cagatay, S. (2015). Examining EFL students' foreign language speaking anxiety. The case at a Turkish state Univers-

ity. Procedia - Social Behavioral Sciences, 199, 648-656. https://doi.org/10.1016/j.sbspro.2015.07.594

Chemagosi, M. J. (2020). The relationship between parental level of education and learners performance in public pre-primary schools in Nandi County, Kenya. International Journal of Scientific Research and Management, 8(3), 1247-1257. doi: 10.18535/ijsrm/v8io3.elo2

Darmawangsa, D., Sukmayadi, V. \& Yahya, A. H. (2020). First-year students' communication apprehension in learning French as foreign language. Indonesian Journal of Applied Linguistics, 10, 340-348. https://doii.org/10.17509/ijal.v1oi2.28599

Dogan, Y. \& Tuncer, M. (2016). Examination of foreign language classroom anxiety and achievement in foreign language in Turkish university students in terms of various variables. Journal of Education and Training Studies, 4(5), 18-29. http://jets.redfame.com

Hailikari, T. \& Ylanne, S. L. (2008). The relevance of prior knowledge in learning and instructional design. American Journal of Pharmaceutical Education, 72(5), 1-8. doi: 10.5688/aj7205113 
Hasan, A., Gushendra, R., \& Yonantha, F. (2017). The influence of prior knowledge on students' listening and reading comprehension. Indonesian Journal of English Education, 4(1), 1-15. http://dx.doi.org/10.15408/ijee. v4i1. 4744

Hosseinpour, V., Sherkatolabbasi, M., \& Yarahmadi, M. (2015). The Impact of parents' involvement in and attitude toward their children's foreign language programs for learning English. International Journal of Applied Linguistic E English Literature, 4(4), 175-185. doi:10.7575/aiac.ijalel.v.4n.4p.175

Khodadady, E. \& Alaee, F. F. (2012). Parent education and high school achievement in English as a foreign language. Theory and Practice in Language Studies, 2(9), 1811 1817. doi: 10.4304/tpls.2.9.1811 1817

Kralova, Z. (2016). Foreign Language Anxiety. https://www.researchgate.net/publication/312918924

Lana, J. K. \& Yahya, A. (2013). Intrinsic and extrinsic motivation, orientation and achievement in L2 of Arab learners of English, French and German: A study from Jordan. International Education studies, 6(12), 52-63. Retrieved from www.ccsenet.org/ies

Liu, T., Lin, Y., \& Paas, F. (2014). Effects of prior knowledge on learning from different compositions of representations in a mobile learning environment. Computer $\mathcal{E}$ Education, 72, 328-338. http://dx.doi.org/ 10.1016/j.compedu.2013.10.019

Leob, S., Dynarski, S., McFarland, D., Morris, P. \& Reardon, S. (2017). Descriptive analysis in education: A guide for researchers. (NCEE 2017-4023, Washington, DC: U.S) http://ies.ed.gov/ncee/

Luo, H. (2014). Foreign language speaking anxiety: A study of Chinese language learners. Journal of the National Council of Less Commonly Taught Languages, 15, 19-117. Retrieved from https://www.researchgate.net/public ation/270645657

Meghar, S. M. K., \& Chuah, J. S. C. (2012). Manufacturing industry employers' perception of graduates' English language skills proficiency. International Journal of Applied Linguistic E English Literature, 1(4), $114-124$. https://doi.org/10.7575/ijalel.v.1n.4p.114

Molnar, D., \& Crnjak, G. (2018). Exploring foreign language communication apprehension among the English Language university students in the English language classroom Setting. European Journal of Social Sciences. Study, 5(2), 27-39. doi:10.2478/ejser-2018-0031

Murith, G. W. (2015). Parental determinants of academic performance of learners in public day secondary schools in Imenti North Sub-county, Meru County, Kenya. (Masters thesis, Kenyatta University, Kenya.)

Muruwei, M. (2011). Parents' level of education and senior secondary students' academic performance in English language in Bayelsa State, Nigeria. JORIND, 9(2) , www.ajol.info/journals/jorind

Musarat, A., Sundus, N., Naz, F., Fozia, P., \& Sameen, A. (2013). Impact of parental education and socio-economic status on academic achievements of university students. European Journal of Psychological Research, 1(3), 19. www.idpublications.org

Mustapha, A. A., \& Khalil, A. A (2018). Oral Communication Apprehension among English Senior Majors at AlQuds Open University in Palestine. International Journal of Research in English Education, 3(1), 44-58. doi:10.29252/ijree.3.1.44

Nioutsikos, I. (2017). The effect of prior knowledge on teaching International History: An empirical case study in UK Higher Education. International Journal of Historical Learning, Teaching and Research, 15(1), 1-10. www.history.org.uk

Nuraqilah, N. M. \& Aminabibi, S. (2019). Investigating English Language Speaking Anxiety among Malaysian Undergraduate learners. Asian Social Science, 15(1), 1-7. https://doi.org/10.5539/ass.v15n1p1

Obinna, A. U., Maduagwu, B. C., Nelson, E., \& Onyeka, G. (2019). Influence of foreign language anxiety on the academic achievement of senior secondary school students in French in Imo state. Language, Literature and Culture, 2(3), 123-126. Retrieved from http://www.aascit.org/journal/llc

Odinye, S. I. (2015). The development of Chinese Language in Nigeria. Interdisciplinary Journal of African $\mathcal{E}$ Asian Studies, 1(1), 1-8.

Odoh, L. C., Ugwuanyi, U. B., Odigbo, B. E. \& Chukwuani, N. V. (2017). Influence of parental occupation and level of education on academic performance of accounting students in Nigeria. Research on Humanities and Social Sciences, 7(10), 21-27. https://www.researchgate.net/publication/323783921

Omonigho, S. (2016). French as Nigeria's second official language. Sunday Magazine. https://m.guardian.ng/sunday-magazine/french-as-nigerias-second-official language/

Ozturk, G. \& Gurbuz, N. (2013). The impact of gender on foreign language speaking anxiety and motivation. Procedia- Social and Behavioral Sciences, 70, 654-665. https://doi.org/10.1016/j.sbspro.2013.01.106

Panferov, S. (2010). Increasing ELL parental involvement in our schools: Learning from the parents. Theory into Practice, 49(2), 106-112. https://doi.org/10.1080/00405841003626551

Rafek, M. B., Ramli, N. H. L., Iksan, H., Harith, N. M., \& Abas, A. I. (2014). Gender and language: Communication apprehension in second language learning. Procedia Social and Behavioral Sciences, 123, 90-96. 
Khan, R. M. A., Iqbal, N. \& Tasneem, S. (2015). The influence of parents educational level on secondary school students academic achievements in district Rajanpur. Journal of Education and Practice, 6(16), 76-79. www.iiste.org

Sadighi, F., \& Dastpak, M. (2017). The sources of foreign language speaking anxiety of Iranian English language learners. International Journal of Education $\mathcal{E}$ Literacy Studies, 5(4), 112-115. Retrieved from http://dx.doi. org/10.7575/aiac.ijels.v.5n.4p.111

Seery, M. K. (2009). The effect of prior knowledge in undergraduate performance in Chemistry: A correlation prediction Study. (Theses, Technological University, Dublin.) https://arrow.tudulin.ie/ltcdis/23

Shabani, M. B. (2013). The effect of background knowledge on speaking ability of Iranian EFL learners. International SAMANM Journal of Marketing and Management, 1(1), 25-33.

Singh, S., Horo, N. \& Singh, V. K. (2016). Parental education and academic performance of students at secondary level. International Journal of Advanced Education and Research, 1(3), 26-29.

Star, J. R., Bethany, R. J., Kathleen, L. \& Natasha, P. (2009). The role of prior knowledge and comparison in the development of strategy flexibility: The case of computational estimation. The International Journal on Mathematics Education, 41(5), 569-579. doi:10.1007/s11858-009-0181-9

Stawiarska, M. \& Malgorzata. (2014). Gender differences in foreign language speaking-in class anxiety. Linguistica Silesiana, 35, 417-434.

Terfassa, A. D. (2018). The relationship between parental education and children's academic performance: The case of Genda Tesfa primary school, Dire Dawa. Research on Humanities and Social Sciences, 8(5), 10-16. www.iiste.org

Vasiliki, G., Muchfield, K., Urbig, D., \& Witteloostuijn, A. V. (2015). The effects of gender and personality on foreign language anxiety among adult multilinguals. Schumpeter Discussion Papers, 2, 1-40. http://nbnresolving.de:hbz:468-20150209151717-3

Wagaba, W. (2010). Foreign language teaching and learning: Challenges and opportunities at Makerere University. Stellenbosch Papers in Linguistic PLUS, 40, 95-109.

Yeh, Y. (2012). Teaching language and culture: The importance of prior knowledge when reading Chinese as a second language. Journal of Multilingual Education Research 3(6), 91-122. http://fordham.bepress.com/jmer

Ying, L. (2018). Gender, academic achievement and communication apprehension in English classroom among Chinese college students. (Masters of Arts, Bangkok University.)

Zashchitina, G. \& Moysyak, N. (2017). Some aspects of developing background knowledge in second language acquisition revisited. Bulgarian Comparative Education Society, 15, 266270.

Zhao, A. \& Whitchurch, A. (2011). Anxiety and its associated factors in college-level Chinese classrooms in the U.S. Journal of Chinese Language Teachers Association, 46(3), 21-47.

Zhou, Y. (2020). The Influence of Family on Children's Second Language Learning. (Major Research Paper, University of Windsor, Ontario Canada.). https://scholar.uwindsor.ca/major-papers/112 